\title{
PENINGKATAN MUTU MADRASAH IBTIDAIYAH: SCHOOL-BASED MANAGEMENT DAN KOMPETENSI GURU MADRASAH
}

\author{
Nuryanto \\ Institut Agama Islam Negeri Metro \\ Jl. Ki Hajar Dewantara 15A Iring Mulyo Kota Metro \\ e-mail:ynur877@gmail.com
}

\begin{abstract}
Madrasah Ibtidaiyah (MI) is an Islamic elementary educational institution that has a certain distinction compared to general elementary education known as Sekolah Dasar (SD). The difference of MI, as a leading elementary school that not only develop general knowledge but also build Islamic character, places it in a very strategic position to build young generation's character since their early ages. Unfortunately, it is widely found in Indonesia that there are still many MIs that have no good quality of education yet. This condition leads to the fact that the people's preference goes more to SD than MI. This article attempts to give brief elaboration school-based management and teachers' competence as the strategies to increase the quality of education in MI so that it becomes the society's choices.
\end{abstract}

Keywords: school based management, teachers' competence, quality of education, Islamic elementary school (MI)

\begin{abstract}
Abstrak
Madrasah Ibtidaiyah (MI) merupakan sebuah lembaga pendidikan dasar Islam yang memiliki distingsi tertentu dari lembaga pendidikan dasar umum. Diferensiasi MI, sebagai sekolah dasar yang tidak hanya mengembangkan pengetahuan umum tetapi juga membangun karakter Islami, menjadikannya ke dalam salah satu posisi strategis untuk membangun karakter generasi muda sejak dini. Akan tetapi, di Indonesia, banyak ditemui MI yang belum memiliki kualitas pendidikan yang baik sehingga masih terlihat jelas bahwa preferensi masyarakat lebih mengarah kepada sekolah dasar umum (SD) daripada MI. Artikel ini mengupas strategi manajemen berbasis sekolah dan peningkatan kompetensi guru yang dapat diimplementasikan dalam rangka meningkatkan mutu pendidikan di MI. Artikel ini membahas school-based management dan peningkatan kompetesi guru sebagai strategi untuk meningkatkana mutu pendidikan di MI sehingga semakin menjadi dapat pilihan masyarakat.
\end{abstract}

Kata kunci: school-based management, kompetensi guru, mutu pendidikan, Madrasah Ibtidaiyah

\section{Pendahuluan}

Tidak dapat dipungkiri bahwa pendidikan adalah sebuah wahana di mana setiap orang diberikan kesempatan untuk meningkatkan potensi yang ada di dalam dirinya. Sebagaimana dikutip dari
Undang-undang Sisdiknas No. 20 tahun 2003, pendidikan merupakan usaha sadar dan terencana untuk mewujudkan suasana belajar dan proses pembelajaran agar peserta didik secara aktif mengembangkan potensi diri untuk memiliki kekuatan spiritual 
keagamaan, pengendalian diri, kepribadian, kecerdasan, akhlak mulia serta keterampilan yang diperlukan dirinya, masyarakat dan bangsa. Oleh karena itu, pendidikan adalah bagian tak terpisahkan dalam kehidupan setiap orang. Pendidikan mempengaruhi pertumbuhan ekonomi suatu bangsa dalam meningkatkan kualitas manusia Indonesia, pemerintah bukanlah suatu sistem yang lepas dengan pihak swasta dan masyarakat. Hubungan yang tak terpisahkan dalam peranannya untuk meningkatkan mutu pendidikan. ${ }^{1}$

Terlepas pentingnya pendidikan bagi bangsa ini, kita masih harus mengakui bahwa kualitas pendidikan Indonesia masih rendah. Sebuah survey yang dirilis oleh .... Menunjukkan bahwa dari 76 negara, Indonesia menempati posisi 69 atau posisi paling rendah ke- $8 .{ }^{2}$ Kita tertinggal jauh dari tetangga kita, Singapura yang menempati posisi pertama dan Vietnam pada posisi 12.

Mengapa mutu pendidikan di Indonesia belum cukup baik dan terkesan stagnan? Ada dua faktor yang menyebabkan mutu pendidikan selama ini kurang berhasil. Pertama, strategi pembangunan pendidikan selama ini lebih bersifat input oriented. Strategi yang demikian lebih bersandar kepada asumsi bahwa bilamana semua input pendidikan telah dipenuhi, maka secara otomatis lembaga pendidikan akan menghasilkan output yang bermutu. Ternyata strategi input-output yang diperkenalkan oleh teori education production function tidak berfungsi sepenuhnya di lembaga pendidikan melainkan hanya terjadi dalam institusi ekonomi. ${ }^{3}$

1 Nanang Fatah, Ekonomi dan Pembiayaan Pendidikan (Bandung: Remaja Rosdakarya, 2000), 77.

2 "Asia tops biggest global school rankings - BBC News," diakses 2 Mei 2018, http://www. bbc.com/news/business-32608772 pada tanggal 6 Desember 2016.

3 Hendyat Soetopo, Pendidikan dan Pembelajaran, Cet I (Malang: UMM Malang, 2005), 94-96.
Kedua, pengelolaan pendidikan selama ini lebih bersifat macro-oriented. Akibatnya, banyakfaktoryang diproyeksikan di tingkat makro dan tidak berjalan sebagaimana mestinya di tingkat mikro (madrasah), sehingga hal ini memberikan pemahaman bahwa pembangunan pendidikan bukan hanya terfokus pada penyediaan faktor input pendidikan tetapi jugaharuslebih memperhatikan faktor proses pendidikan.Inputpendidikanmerupakanhal yang mutlak harus ada dalam batas tertentu tetapi tidak menjadi jaminan dapat secara otomatis meningkatkan mutu pendidikan (school resources arenecessary but not sufficient condition to improve student achievement). Disamping itu mengingat sekolah sebagai unit pelaksana pendidikan formal terdepan dengan berbagai keragaman potensi anak didik yang memerlukan layanan pendidikan yang beragam, kondisi lingkungan yang berbeda, maka sekolah harus dinamis dan kreatif dalam melaksanakan perannya mengupayakan peningkatan mutu pendidikan, agar mutu tetap terjaga dan proses peningkatan mutu tetap terkontrol, maka harus ada standar yang diaturdan disepakati secara nasional untuk dijadikan indikator evaluasi keberhasilan peningkatan mutu tersebut. Pemikiran ini mendorong munculnya pendekatan baru, yakni pengelolaan peningkatan mutu pendidikan di masa mendatang harus berbasis sekolah sebagai institusi paling depan dalam kegiatan pendidikan. Pendekatan ini, kemudian dikenal dengan manajemen peningkatan mutu pendidikan.

Rendahnya kualitas pendidikan juga sangat terasa di sekolah-sekolah Islam atau yang berada di bawah Kementrian Agama. Realitas Pendidikan Islam saat ini bisa dibilang telah mengalami masa intellectual deadlock. ${ }^{4}$ Diantara indikasinya

4 Abd Rachman Assegaf, Membangun Format Pendidikan Islam di Era Globalisasi, Cet 2 (Yogyakarta: ArRuzz Media, 2004), 1. 
adalah minimnya upaya pembaharuan, dan kalau ada kalah cepat dengan perubahan sosial, politik dan kemajuan iptek. Kedua, praktek pendidikan Islam sejauh ini masih memelihara warisan lama dan tidak banyak melakukan pemikiran kreatif, inovatif dan kritis terhadap isu-isu aktual. Ketiga, model pembelajaran pendidikan Islam menekankan pendekatan intelektualisme-verbalistik dan menegasikan pentingnya interaksi edukatif dan komunikasi humanistic antara gurumurid. Keempat, orientasi pendidikan Islam menitik beratkan pada pembentukan hamba Allah dan tidak seimbang dengan pencapaian karakter manusia muslim sebagai khalifatu fi al-ardi. ${ }^{5}$

\section{Tinjauan Pustaka}

\section{Pendidikan Dasar: Madrasah Ibtidaiyah}

Suharjo (2006: 1) menyatakan bahwa "sekolah dasar pada dasarnya merupakan lembaga pendidikan yang menyelenggarakan program pendidikan enam tahun bagi anak-anak usia 6-12 tahun." Hal senada juga diungkapkan Fuad Ihsan (2008: 26) bahwa "sekolah dasar sebagai satu kesatuan dilaksanakan dalam masa program belajar selama 6 tahun." Mencermati kedua pernyataan Suharjo dan Fuad Ihsan dapat dijelaskan bahwa sekolah dasar merupakan jenjang pendidikan yang berlangsung selama enam tahun.

Pernyataan tentang sekolah dasar lainnya yang dikemukakan oleh Harmon \& Jones (2005: 1) bahwa:

"Elementary schools usually serve children between the ages of five andeleven years, or kindergarten through sixth grade. Some elementary schools comprise kindergarten through fourth grade and are calledprimary schools. These schools are usually followed by a middle school, which includes fifth through eighth grades. Elementary schools can alsorange from kindergarten to eighth grade".
Pernyataan oleh Harmon \& Jones agak berbeda dengan yang dikemukakan oleh Suharjo yaitu terletak pada usia. Jika Suharjo menyatakan sekolah dasar lebih ditunjukkan pada anak yang berusia 6-12 tahun, maka Harmon dan Jones menyatakan sekolah dasar biasanya terdiri atas anakanak antara usia 5-11 tahun, atau TK sampai kelas enam. Kemungkinan perbedaan ini terletak pada fisik antara anak yang ada di Indonesia dan anak yang ada dinegara Eropa dan sekitarnya.

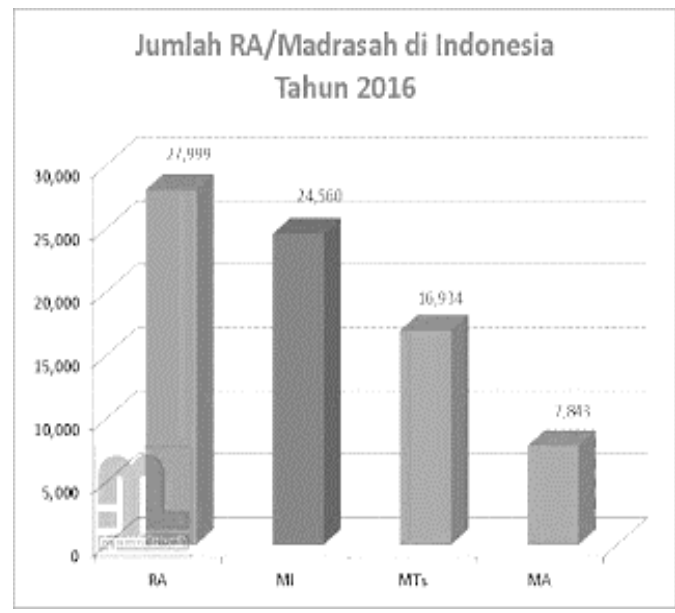

Di Indonesia, terdapat dua jenis pendidikan dasar yakni sekolah dasar (SD) yang berada di bawah Kemendiknas dan madrasah ibtidaiyah (MI) yang berada di bawah naungan Kementrian Agama. Menurut data yang dilansir oleh situs Emis PendisKemenag, jumlahmadrasahibtidaiyah adalah sebanyak 24.560. Dari jumlah ini, terdapat 1.686 Madrasah Ibtidaiyah Negeri dan 22.874 Madrasah Ibtidaiyah Swasta.

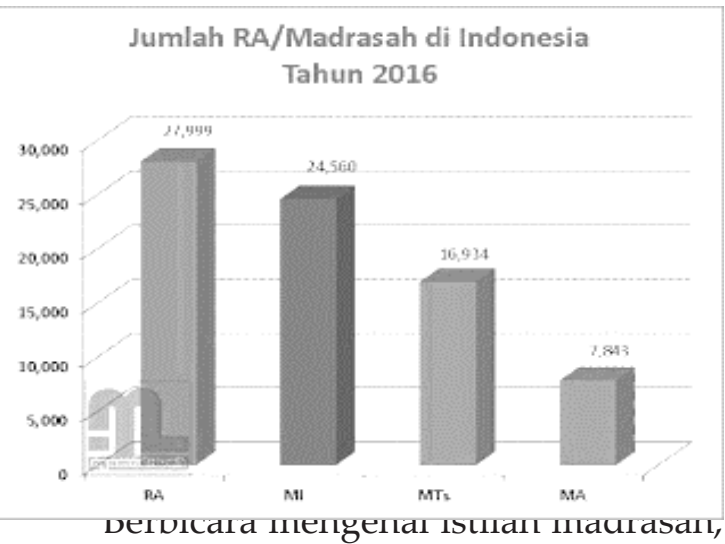

5 Assegaf, 8-9. 
apabila kita melihat sejarah perkembangan madrasah di Indonesia, Muhammad Qosim (2007) menyatakan bahwa madrasah dibagi menjadi dua jenis, yaitu madrasah diniyah dan madrasah non-diniyah. Perbedaannya adalah madrasah diniyah merupakan lembaga pendidikan keagamaan yang kurikulumnya $100 \%$ berisi tentang materi agama. Sedangkan madrasah non-diniyah adalah lembaga pendidikan keagamaan yang kurikulumnya, di samping materi agama, meliputi mata pelajaran umum dengan prosentase beragam. ${ }^{6}$

Seiring dengan perubahan kebijakan pemerintah dalam dunia pendidikan, makna madrasah (khususnya pada madrasah nondiniyah) mengalami perubahan. Semula madrasah dipandang sebagai institusi pendidikan keagamaan. Kemudian, terutama pasca pengesahan UU Sistem Pendidikan Nasional Nomor 2/1989, madrasah dipandang sebagai sekolah umum berciri khas Islam, atau dapat dikatakan "sekolah plus". Perubahan definisi tersebut berimplikasi pada perubahan kurikulum, status, dan fungsi madrasah dalam sistem pendidikan nasional.

\section{Konsep Mutu}

\section{Pengertian Mutu Pendidikan}

Apa yang disebut dengan mutu atau kualitas? Downey, Frase, dan Peters (1994) menyatakan bahwa" quality is meeting, exceeding, and satisfying a community's needs and expectations with the recognition that these needs and desireswill change over time." Menurut mereka, kualitas adalah memenuhi, melampaui, dan memuaskan harapan dan kebutuhan sebuah kelompok tertentu dengan tetap menyadari bahwa kebutuhan-kebutuhan ini akan berubah seiring perubahan waktu.

Dalam konteks pendidikan, terdapat

6 Muhammad Qosim, "Madrasah di Indonesia (Pertumbuhan dan Perkembangan)," Jurnal Tadris 2, no. 1 (2007): 41-57. berbagai definisi yang dikemukakan. Adam (1993) menyatakan bahwa mutu pendidikan mencakup beberapa komponen yakitu: efisiensi, efektiviyas, kesetaraan dan kualitas itu sendiri. Mengacu ke beberapa definisi yang sudah ada, UNICEF merumuskan beberapa elemen yang termasuk ke dalam mutu pendidikan ${ }^{7}$ :

1. Peserta didik yang sehat dan siap untuk berpartisipasi dalam proses pembelajaran, serta didukung dalam belajar oleh keluarga dan lingkungan mereka.

2. Terdapat lingkungan belajar yang bersih, aman dan sensitif gender dan menyediakan sumber serta fasilitas yang memadai.

3. Konten yang direfleksikan ke dalam kurikulum dan bahan ajar yang relevan untuk pemerolehan keterampilan dasar (basic skills) terutama di bidang literasi, berhitung dan kecakapan hidup dan pengetahuan di bidang-bidang seperti gender, kesehatan, gizi, sosial serta perdamaian.

4. Proses di mana para pendidik menggunakan pendekatan pengajaran yang terpusat pada peserta didik (studentcentered) di dalam ruang kelas dan sekolah yang tertata dengan baik. Juga, penilaian yang valid untuk memfasilitasi proses pembelajaran dan mengurangi kesenjangan.

Definisi ini mengakomodir pemahaman bahwa pendidikan merupakan sebuah sistem yang kompleks yang tertanam di dalam konteks politis, kultural dan ekonomis. Definisi ini juga memperhitungkan pengaruh global dan internasional yang mendorong pembahasan kualitas pendidikan (Motala, 2000). ${ }^{8}$

7 2000. https://www.unicef.org/education/ files/n.PDF

8 Motala S, "Education transformation and quality: The South African experience" (the Annual Meeting of the Comparative and International 
Sementara itu, David Chapman dan Don Adams mendefinisikan kualitas pendidikan mencakup "inputs (numbers of teachers, amount of teachertraining, number of textbooks), processes (amount of direct instructional time,extent of active learning), outputs (test scores, graduation rates), andoutcomes (performance in subsequent employment)". ${ }^{9}$ Definisi ini terlihat riil dan terukur karena memberikan kriteria yang jelas mengenai kualitas pendidikan yakni: input, process, output dan outcome. Input terdiri dari jumlah guru, pelatihan guru dan ketersediaan buku ajar. Kemudian proses terdiri dari jumlah durasi kegiatan belajar mengajar, dan tingkat keaktifan belajar. Selanjutnya, output terdiri dari nilai tes dan tigkatkelulusan. Akhirnya masuk keoutcome yang merupakan tingkat keterterimaan lulusan di dunia kerja. Untuk poin terakhir apabila disesuaikan dengan tingkat MI, maka outcome adalah tingkat keterterimaan siswa di sekolah-sekolah lanjutan yang memiliki reputasi baik.

\section{Faktor-Faktor Yang Mempengaruhi Peningkatan Mutu Pendidikan}

Dalam peningkatan mutu pendidikan pendidkan dapat dipengaruhi oleh faktor input pendidikan dan faktor proses manajemen pendidikan. Input pendidikan adalah segala sesuatu yangharus tersedia karena dibutuhkan untuk berlangsungnya proses. Input pendidikan terdiri dari seluruh sumber daya sekolah yang ada. Komponen dan sumber daya sekolah menurut Subagio Admodiwirio (2000, hal. 22) terdiridari (man), dana (money), sarana dan prasarana (material) serta peraturan (policy).

Dari pengertian diatas maka input pendidikan yang merupakan faktor mempengaruhi mutu pendidikan dapat

Education Society, San Antonio, Texas, Maret 2000).

9 David Chapman dan Don Adams, "The Quality of Education:Dimensions and Strategies," Education in Developing Asia 5 (2002). berupa:

1. Sumber daya manusia sebagai pengelola sekolah yang terdiri dari :

a) Kepala sekolah, merupakan guru yang mendapat tugas tambahan sebagai kepala sekolah. (Sisdiknas tahun 2003 Bab II Pasal 2)

b) Guru, menurut UU Nomor 14 tahun 2005 Bab I pasal 1 menyatakan bahwa guru adalah pendidik profesional dengan tugas utama mendidik, mengajar, membimbing, mengarahkan, melatih, menilai dan mengevaluasi peserta didik.

c) Tenaga administrasi.

2. Sarana dan prasarana.

Menurut Hadiyanto (2004, hal.100) menyatakan bahwa proses pembelajaran tidak hanya komponen guru, peserta dan kurikulum saja, kehadiran sarana dan prasarana pendidikan sudah menjadi suatu keharusan dalam mencapai keberhasilan pembelajaran. Oemar Hamalik (2004, hal.22), mengemukakan Sarana dan prasarana pendidikan, merupakan media belajar atau alat bantu yang pada hakikatnya akan lebih mengefektifkan komunikasi dan interaksi antara guru dan siswa dalam proses pendidikan.

\section{Kesiswaan}

Siswa sebagai peserta didik merupakansalahsatuinputyangturutmenentukan keberhasilan proses pendidikan. Penerimaan peserta didik didasarkan atas kriteria yang jelas, transparan dan akuntabel.

\section{Keuangan (Anggaran Pembiayaan)}

Salah satu faktor yang memberikan pengaruh tehadap peningkatan mutu dan kesesuaian pendidikan adalah anggaran pendidikan yang memadai. Sekolah harus mimiliki dana yang cukup untuk menyelenggarakan pendidikan. Oleh karenna itu dana pendidikan sekolah harus dikelola dengan transparan dan efesien. 
5. Kurikulum.

Salah satu aplikasi atau penerapan metode pendidikan yaitu kurikulum pendidikan. Pengertian kurikulum berdasarkanHildaTabayang ditulisolehWina Sanjaya (2005, hal.5) adalah suatu program atau rencana pembelajaran. Kurikulum merupakan komponen substansi yang utama di sekolah. Prinsip dasar dari adanya kurikulum ini adalah berusaha agar proses pembelajaran dapat berjalan dengan baik, dengan tolak ukur pencapaian tujuan oleh siswa dan mendorong guru untuk menyusun dan terus menerus menyempurnakan strategi pembelajarannya.

6. Keorganisasian

Pengorganisasian sebuah lembaga pendidikan, merupakan faktor yang dapat membantu untuk meningkatkan kualitas mutu dan pelayanan dalam lembnaga pendidikan. Pengorganisasian merupakan kegiatan yang mengatur dan mengelompokkan pekerjaan ke dalam bagian-bagian yang lebih kecil dan lebih mudah untuk ditangani.

7. Lingkungan fisik.

Belajar dan bekerja harus didukung oleh lingkungan. Gordon dalam Hadiyanto (2004, hal.100), lingkungan berpengaruh terhadap aktivitas baik terhadap guru, siswa termasuk didalamnya aktivitas pembelajaran.

8. Perkembangan ilmu pengetahuan ilmu pengetahuan / teknologi.

Disamping faktor guru dan sarana lainnya yang berkaitan dengan dunia pendidikan yaitu faktor eksternal yang berupa perkembangan ilmu pengetahuan dan teknologi. Sekolah sebagai tempat memperoleh ilmu pengetahuan dan berfungsi sebagai transper ilmu pengetahuan kepada siswa, dituntut untuk mengikuti perkembangan ilmu pengetahuan dan

teknologi saat ini, sesuai dengan bidang pengajarannya.
9. Peraturan

Dalam upaya meningkatkan mutu pendidikan nasional dan untuk menghasilkan mutu sumber daya manusia yang unggul serta mengejar ketertinggalan disegala aspek kehidupan yang disesuaikan dengan perubahan global dan perkembangan ilmu pengetahuan dan teknologi, bangsa Indonesia melalui DPR RI pada tanggal 11 Juni 2003 telah mengesahkan Undangundang Sisdiknas yang baru, sebagai pengganti Undang-undang Sisdiknas nomor 2 tahun 2009.

10. Partisipasi atau Peran serta masyarakat.

Partisifasi masyarakat dalam dunia pendidikan diharapkan menjadi tulang punggung, sedangkan pihak pemerintah sebatas memberikan acuan dan binaan dalam pelaksanaan program kegiatan sekolah. HAR Tillar (1992, hal.58) menyatakan bahwa peran serta masyarakat didalam penyelenggaraan pendidikan berarti pula pemberdayaan masyarakat itu sendiri didalam ikut serta menentukan arah dan isi pendidikan.

\section{Kebijakan Pendidikan}

Salah satu peran pemerintah dalam meningkatkan mutu pendidikan adalah melakukan desentralisasi pendidikan. Dengan adanya desentralisasi tersebut, maka berbagai tantangan untuk pemerataan dan peningkatan mutu pendidikan mengharuskan adanya reorientasi dan perbaikan sistem manajemen penyelenggaraan pendidikan. Selain faktor input yang telah dikemukakan tersebut, faktor lain yang menentukan mutu pendidikan adalah proses manajeman pendidikan. Abdul Hadis dan Nurhayati didalam manajemen mutu pendidikan, (2010, hal. 100-101) mengemukakan secara garis besar, ada dua faktor utama yang mempengaruhi mutu proses dan hasil belajar mengajar dikelas, yaitu faktor internal dan faktor eksternal. Adapun yang termasuk kedalam faktor internal berupa : faktor psikologis, sosiologis, dan fisiologis yang 
ada pada diri siswa dan guru. Sedangkan yang termasuk kedalam faktor eksternal ialah semua faktor yang mempengaruhi proses hasil belajar mengajar di kelas selain faktor siswa dan guru.

\section{Strategi Peningkatan Madrasah}

\section{a. Pemenuhan Kebutuhan Belajar}

Setiap murid MI memiliki kebutuhan yang berbeda. Oleh karena itu, untuk memenuhi kebutuhan belajar maka perlu dilakukan analisa kebutuhan. Menurut Nunan, sebagaimana dikutip oleh Haque (2014), analisa kebutuhan merupakan sebuah prosedur untuk mendapatkan informasi mengenai peserta didik dan kegiatankegiatan pembelajaran dalam rangka penyusunan silabus.Analisa kebutuhan merupakan bagian penting untuk menyusun bahan ajar pembelajaran bahasa. Ketika materi pengajaran bahasa didesain, guru sangat perlu untuk memiliki informasi yang terpercaya tentang variable peserta didik sehingga ia dapat meminimalisir kesenjangan antara peserta didik, guru dan bahan ajar. ${ }^{10}$ Brown, sebagaimana dikutip oleh Bilokcuoglu (2012) menyatakan bahwa analisa kebutuhan adalah seperangkat kegiatan untuk mengumpulkan informasi yang akan digunakan sebagai dasar pengembangan kurikulum yang dapat memenuhi kebutuhan belajar sekelompok peserta didik. ${ }^{11}$

Menururt Nunan, analisis kebutuhan adalah proses untuk mengumpulkan informasi yang berkaitan dengan kebutuhan pembelajar. Sebelum melakukan analisis, terlebih dahulu harus diketahui perbedaan antara target needs dan learning needs. Sementara itu, Hutchinson dan Waters

${ }^{10}$ Haque. N, "A Brief Study on Need Analysis," International Journal of Multi Disciplinary Research 1, no. 1 (2014).

${ }^{11}$ Bilokcuoglu, "English For Specific Purposes: 'A paper on the special area of English of the nonspecialist ESP Englishinstructor," EUL Journal of Social Sciences III, no. I (Juni 2012): 84. mengklasifikasikan needs ke dalam target needs (apa yang peserta didik perlukan untuk dapat berkomunikasi pada target situasi) dan learning needs (apa yang peserta didik perlukan untuk belajar). Selanjutnya target needs dibagi lagi menjadi:

1) Necessities: aspek bahasa apakah yang diperlukan peserta didik agar dapat berfungsi secara efektif sesuai sasaran.

2) Lacks: Apa yang belum dikuasai peserta didik.

3) Wants: apa yang ingin dipelajarai oleh peserta didik.

Pendapat yang sama juga dinyatakan oleh Richards (2001), ia menyatakan prosedur yang digunakan untuk mengumpulkan informasi tentang kebutuhan peserta didik dikenal dengan istilah analisis kebutuhan. ${ }^{12}$ Analisa kebutuhan dilakukan untuk menjawab ketepatan dan kesesuaian program dengan pembelajar, dengan kurikulum dan situasi-situasi dimana proses pembelajaran akan dilaksanakan. Untuk melaksanakan analisa kebutuhan, ada beberapa langkah yang harus dilakukan yaitu: pengumpulan informasi, identifikasi kesenjangan, analisis performance, identifikasi hambatan, identifikasi karakteristik siswa, identifikasi prioritas, tujuan dan perumusan masalah.

\section{b. Manajemen Berbasis Sekolah (School- Based Management)}

Madarasah ibtidaiyah seyogyanya menerapkan manajemen berbasis sekolah. Dalam buku panduan Manajemen Berbasis Sekolah (MBS) yang disusun oleh Departemen Pendidikan Nasional pada Tahun 2006, Manajemen Berbasis Sekolah diartikan sebagai model pengelolaan yang memberikan otonomi (kewenangan dan tanggungjawab) lebih besar kepada sekolah, memberikan fleksibilitas/ keluwesan-

${ }^{12}$ Bilokcuoglu, “English For Specific Purposes: 'A paper on the special area of English of the nonspecialist ESP Englishinstructor." 
keluwesan kepada sekolah, dan mendorong partisipasi secara langsung warga sekolah (guru, siswa, kepala sekolah, karyawan) dan masyarakat (orangtua siswa, tokoh masyarakat, ilmuwan, pengusaha, dsb), untuk meningkatkan mutu sekolah berdasarkan kebijakan pendidikan nasional serta peraturan perundang-undangan yang berlaku. $^{13}$

Sementara itu, Caldwell dalam Heyward dkk, menyatakan bahwa "School-based management is the systematic decentralization to the school level of authority and responsibility to make decisions on significant matters related to school operations within a centrally determined framework of goals, policies, curriculum, standards, and accountability". ${ }^{14}$ Maksudnya adalah manajemen berbasis sekolah merupakan sebuah desentralisasi sistematis bagi sekolah untuk dapat memiliki otoritas untuk menentukan kebijakankebijakan terkait dengan keberlangsungan sekolah. Manajemen Berbasis Sekolah mencakup beberapa aspek seperti tujuan, kebijakan, kurikulum standard an akuntabilitas.

Minimal terdapat dua alasan mengapa manajemen berbasis sekolah perlu diimplementasikan. Yang pertama, sistem ini mengarah kepada perbaikan manajemen dan operasional sekolah. Yang kedua, manajemen berbasis sekolah dapat menciptakan sebuah kondisi yang dapat mengembangkan proses pengajaran dan pembelajaran. Menurut hasil penelitian Decentralized Basic Education 1 (DBE 1), manajemen berbasis sekolah dapat diimplementasikan di sekolah-sekolah dasar

${ }^{13}$ Bangun Ferdinand, MANAJEMEN BERBASIS SEKOLAH(Survei Tentang Manajemen Berbasis Sekolah Berdasarkan Prinsip-Prinsip Tata Kelola Sekolah Yang Baik di Sekolah Menengah (Medan: Universitas Sumatera Utara, 2009).

14 Mark Heyward, Robert Cannon, dan Sarjono, "Implementing School-Based Management in Indonesia" (Research Triangle Park, NC: RTI Press, 3 Oktober 2011), https://doi.org/10.3768/rtipress.2011. op.0006.1109. di Indonesia dan menghasilkan manajemen dan tata kelola yang lebih baik. ${ }^{15}$

Di dalam menerapkan manajemen berbasis sekolah ini, ada beberapa prinsip yang harus diperhatikan melalui pemberian wewenang dan tanggungjawab yang lebih besar kepada sekolah yang dilaksanakan berdasarkan prinsip-prinsip tata kelola sekolah yang baik yaitu partisipasi, transparansi, dan akuntabilitas.

1. Peningkatan Partisipasi

Peningkatan partisipasi yang dimaksud adalah penciptaan lingkungan yang terbuka dan demokratik, dimana warga sekolah (guru, siswa, karyawan) dan masyarakat (orangtua siswa, tokoh masyarakat, ilmuwan, usahawan, dan sebagainya) didorong untuk terlibat secara langsung dalam penyelenggaraan pendidikan, mulai dari pengambilan keputusan, pelaksanaan, dan evaluasi pendidikan. Hal ini dilandasi oleh keyakinan bahwa jika seseorang dilibatkan dalan penyelenggaraan pendidikan, maka yang bersangkutan akan mempunyai "rasa memiliki" terhadap sekolah, sehingga yang bersangkutan juga akan bertanggung jawab dan berdedikasi sepenuhnya untuk mencapai tujuan sekolah.

2. Peningkatan Transparansi

Para pengamat pendidikan beranggapan bahwa selama ini, terutama sebelum era desentralisasi dan reformasi, pengelolaan pendidikan di banyak sekolah sangat tertutup bagi pihak luar. Masyarakat, orangtua murid dan sebagian besar guru tidak banyak mengetahui seluk beluk pengelolaan pendidikan di sekolah, tidak mengetahui pendapatan dan belanja sekolah, tidak dilibatkan di dalam mengevaluasi

${ }^{15}$ Decentralized Basic Education 1 study (RTI International, 2010). Hasil report lengkap dapat diakses di the United States Agency for International Development's (USAID's) Development Experience Clearinghouse and from the project website, http:// www.dbe-usaid.org. 
kekuatan dan kelemahan kinerja sekolah dan sebagainya.

Pengembangan transparansi ditujukan untuk membangun kepercayaan dan keyakinan publik kepada sekolah bahwa sekolah adalah organisasi pelayanan pendidikan yang bersih dan berwibawa. Bersih dalam arti tidak KKN dan berwibawa dalam arti professional. Transparansi bertujuan untuk menciptakan kepercayaan timbalbalik antara sekolah dan publik melalui penyediaan informasi yang memadai dan menjamin kemudahan dalam memperoleh informasi yang akurat (Depdiknas dalam Panduan Manajemen Berbasis Sekolah, 2006:14).

Peningkatan Akuntabilitas

\begin{tabular}{llr}
\multicolumn{1}{r}{ Prinsip } & $\begin{array}{c}\text { berikutnya yang harus } \\
\text { diupayakan }\end{array}$ adalah akuntabilitas. \\
Akuntabilitas & adalah kewajiban untuk \\
memberikan pertanggungjawaban atau
\end{tabular}
untuk menjawab dan menerangkan kinerja dan tindakan penyelenggaran organisasi kepada pihak yang memiliki hak atau wewenang untuk meminta keterangan atau pertanggungjawaban (Slamet, 2006:37).

Tujuan utama akuntabilitas adalah untuk mendorong terciptanya akuntabilitas kinerja sekolah sebagai salah satu prasyarat untuk terciptanya sekolah yang baik dan dapat dipercaya. Penyelenggara sekolah harus memahami bahwa mereka harus mempertanggungjawabkan hasil kerja kepada publik. Selainitu, tujuan akuntabilitas adalah untuk menilai kinerja sekolah dan kepuasan publik terhadap pelayanan pendidikan yang diselenggarakan oleh sekolah, untuk mengikutsertakan publik dalam pengawasan pelayanan pendidikan, dan untuk mempertanggungjawabkan komitmen pelayanan pendidikan kepada publik (Depdiknas dalam Panduan Manajemen Berbasis Sekolah, 2006:14).

\section{c. Meningkatkan Kompetensi Guru}

Tidak dapat dipungkiri bahwa meningkatkan kualitas guru di madrasah ibtidaiyah merupakan suatu hal yang sangat urgen. Meskipun guru dan pengajar bukan satu-satunya faktor penentu kesuksesan keiatan pendidikan, tetapi pengajaran merupakan titik sentral pendidikan dan kualifikasi sebagai cermin kualitas tenaga pengajar memberikan andil sangat besar pada kualitas pendidikan yang menjadi tanggung jawabnya.

Kebanyakan guru belum memiliki profesionalisme yang memadai untuk menjalankan tugasnya sebagaimana disebut dalam pasal 39 UU No 20/2003 tentang sistem pendidikan nasional yaitu merencanakan pembelajaran, melaksanakan pembelajaran, menilai hasil pembelajaran, melakukan pembimbingan, melakukan pelatihan, melakukan penelitian dan melakukan pengabdian masyarakat. Kemudian menurut undang-undang No. 14/2005 tentang Guru dan Dosen, pekerjaan guru hanya dapat dilakukan oleh seseorang yang mempunyai kualifikasi akademik, kompetensi, dan sertifikat pendidik sesuai dengan persyaratan untuk setiap jenis dan jenjang pendidikan tertentu. Guru sebagai tenaga profesional sebagaimana dimaksud dalam Pasal 2 ayat (1) berfungsi untuk meningkatkan martabat dan peran guru sebagai agen pembelajaran. Yang dimaksud dengan guru sebagai agen pembelajaran (learning agent) adalah peran guru antara lain sebagai fasilitator, motivator, pemacu, perekayasa pembelajaran, dan pemberi inspirasi belajar bagi peserta didik.

Dalam pendidikan Islam, Natsir (2007) menyatakan bahwaguru merupakan tulang punggung yang memiliki eksistensi yang sangat kuat. Menurut Syekh az-Zamuji dalam kitabnya Ta'lim Muta'lim di antara syarat seseorang untuk dapat belajar dengan sukses adalah menghormati guru sama seperti menghormati ilmu. Santri (siswa) tidak akan memperoleh ilmu dan mendapat manfaatnya tanpa menghormati ilmu dan gurunya. Demikian besar posisi dan fungsi 
guru sehingga menghormatinya itu lebih baik dibandingkan sekedar mentaatinya. Menurut kitab rujukan utama para santri ini, manusia tidak dianggap kufur karena bermaksiat. Tetapi manusia menjadi kufur karena tidak menghormati atau memuliakan perintah Allah. ${ }^{16}$

Adapaun beberapa cara yang dapat dilakukan untuk meningkatkan kompetensi guru madrash ibtidaiyah adalah dengan melakukan beberapa hal sebagai berikut:

1) Penelitian tindakan kelas (PTK). Pihak madrasah seharusnya menekankan kepada para guru untuk melakukan PTK agar dapat meningkatkan kompetensi pedagogic guru. PTK dimaksudkan untuk memperbaiki mutu dan praktik pembelajaran yang dilaksanakan guru demi tercapainya tujuan pembelajaran, memperbaiki dan meningkatkan kinerja-kinerja pembelajaran yang dilaksanakan oleh guru, mengidentifikasi, menemukan solusi dan mengatasi masalah pembelajaran di kelas agar pembelajaran bermutu, meningkatkan dan memperkuat kemampuan guru dalam memecahkan masalah-masalah pembelajaran dan membuat keputusan yang tepat bagi siswa dan kelasyang diajarnya. ${ }^{17}$

2) Pelatihan (training). Tujuan dilaksanakan pelatihan adalah menambah pengetahuan guru, menambah keterampilan guru, mengubah dan membentuk sikap guru, mengembangkan keahlian pegawai sehingga pekerjaan dapat

16 Nanat F. Natsir, "Pemberdayaan Kualitas Guru dalam Perspektif Pendidikan Islam," Educationist 1, no. 1 (2007): 20-27.

17 Sukanti, "Meningkatkan Kompetensi Guru Melalui Penelitian Tindakan Kelas," Jurnal Pendidikan Akuntansi Indonesia VI, no. 1 (2008): 1-11. diselesaikan dengan lebih cepat dan efektif, mengembangkan semangat, kemajuan, dan antusiasme para guru. ${ }^{18}$

3) Evaluasi kinerja guru. Meskipun pihak pemerintah juga melakukan beberapa upaya untuk mengevaluasi kinerja guru, pihak madrasah ibtidaiyah perlu secara regular mengevaluasi kinerja guru secara independen. Evaluasi kinerja dalam hal ini disebut juga dengan penilaian kinerja. Penilaian dilakukan secara sitematis terhadap kinerja para guru madrasah dan potensi mereka untuk berkembang. Penilaian kinerja mencakup prestasikerja, carabekerja, dan pribadi mereka. Sedangkan penilaian terhadap potensi untuk berkembang mencakup kreativitas dan hasil belajar atau kemampuan mengembangkan profesinya. ${ }^{19}$

4) Reward bagi guru berprestasi. Agar para guru madrasah ibtidaiyah merasa bahwa kerja kerasnya diapresiasi oleh pihak madrasah, maka perlu adanya reward atau penghargaan. Yang dimaksud dengan prestasi kerja ialah hasil pekerjaan, apakah pekerjaan tersebut sudah sesuai dengan kritetia yang telah ditentukan sebelumnya dan apakah sudah tepat penyelesaiannya dengan alokasi waktu yang telah diberikan. Apakah hasil pekerjaan itu sudah memenuhi akuntabilitas atau sekedar selesai. Cara bekerja mencakup ciri-ciri efektivitas dan efifiensi dalam bekerja.

18 Kornelius, Margono, dan Hartutiningsih, "Pendidikan dan Pelatihan Guru dalam Meningkatkan Kualitas Pendidikan di SMP Negeri 27 Sendawar Kabupaten Kutai Barat," Journal Administrative Reform 2, no. 3 (2014): 1811-23.

19 Made Pidarta, Manajemen Pendidikan Indonesia, Cet.ke-2 (Jakarta: Rineka Cipta, 2004), 135. 


\section{Simpulan}

Madrasah harus mampu berlari lebih kencang agar dapat mnjadi lembaga pendidikan dasar yang dianggap sebelah mata. Untuk mencapai hal ini peningkatan mutu pendidikan di MI menjadi sesuatu yang tak terelakkan. Meski banyak ditemukan MI yang memiliki kualitas pendidikan yang baik, ada beberapa strategi yang dapat diterapkan untuk mengatasi permaslahan ini, antara lain dengan mengadakan analisa kebutuhan, manajemen berbasis sekolah (school-based management) dan peningkatan kompetensi guru. Untuk dapat mengimplementasikan strategistrategi ini, pihak sekolah khususnya kepala madrasah harus mampu melihat karakter dan potensi di lembaganya. Kemudian, kualitas teamwork di dalam madrasah serta budaya saling mendukung di setiap divisi juga harus dijalin secara konsisten. Semua stake holder harus berfikir dan berusaha memprioritaskan keberhasilan madrasah, bukan kepentingan individu. ketika hal-hal tersebut sudah berjalan dengan baik, maka masalah-masalah klasik seperti rendahnya fasilitas dan kurangnya kesejahteraan tenaga pendidik maupun kependidikan akan dapat diminimalisir secara bertahap.

\section{Daftar Pustaka}

"Asia tops biggest global school rankings - BBC News." Diakses 2 Mei 2018. http://www.bbc.com/news/business32608772.

Assegaf, Abd Rachman. Membangun Format Pendidikan Islam di Era Globalisasi. Cet 2. Yogyakarta: ArRuzz Media, 2004.

Bilokcuoglu. “English For Specific Purposes: 'A paper on the special area of English of the non-specialist ESP Englishinstructor." EUL Journal of Social Sciences III, no. I (Juni 2012).
Chapman, David, dan Don Adams. "The Quality of Education:Dimensions and Strategies." Education in Developing Asia 5 (2002).

Fatah, Nanang. Ekonomi dan Pembiayaan Pendidikan. Bandung: Remaja Rosdakarya, 2000.

Ferdinand,Bangun.MANAJEMENBERBASIS SEKOLAH(Survei Tentang Manajemen Berbasis Sekolah Berdasarkan PrinsipPrinsip Tata Kelola Sekolah Yang Baik di Sekolah Menengah. Medan: Universitas Sumatera Utara, 2009.

Heyward, Mark, Robert Cannon, dan Sarjono. "Implementing School-Based Management in Indonesia." Research Triangle Park, NC: RTI Press, 3 Oktober 2011. https://doi.org/10.3768/ rtipress.2011.op.0006.1109.

Kornelius, Margono, dan Hartutiningsih. "Pendidikan dan Pelatihan Guru dalam Meningkatkan Kualitas Pendidikan di SMP Negeri 27 Sendawar Kabupaten Kutai Barat." Journal Administrative Reform 2, no. 3 (2014).

N, Haque. "A Brief Study on Need Analysis." International Journal of Multi Disciplinary Research 1, no. 1 (2014).

Natsir, Nanat F. "Pemberdayaan Kualitas Guru dalam Perspektif Pendidikan Islam." Educationist 1, no. 1 (2007).

Pidarta, Made. Manajemen Pendidikan Indonesia. Cet.ke-2. Jakarta: Rineka Cipta, 2004.

Qosim, Muhammad. “Madrasah di Indonesia (Pertumbuhan dan Perkembangan)." Jurnal Tadris 2, no. 1 (2007).

S, Motala. "Education transformation and quality: The South African experience." dipresentasikan pada the Annual Meeting of the Comparative and International Education Society, 
32| Mlementirly Vol. 4 Edisi Januari-Juni 2018

San Antonio, Texas, Maret 2000.

Soetopo, Hendyat. Pendidikan dan Pembelajaran. Cet I. Malang: UMM Malang, 2005.

Sukanti. "Meningkatkan Kompetensi Guru Melalui Penelitian Tindakan Kelas." Jurnal Pendidikan Akuntansi Indonesia VI, no. 1 (2008). 